\title{
The Implementation of Poverty Alleviation Policy of Traditional Fishermen in Palopo, Indonesia
}

\author{
Nurkaidah \\ Mappa Nasrun \\ Andi Munarfah M. \\ Firdaus Suhaeb \\ Department of Public Administration, Universitas Negeri Makassar \\ Kampus Gunung Sari Baru Jln. Bonto Langkasa, Makassar, South Sulawesi, Indonesia \\ Email: kaidah.nur@yahoo.com, nasrun.mappa@yahoo.com,suhaebfirdaus@gmail.com
}

Doi:10.5901/mjss.2016.v7n6p253

\section{Abstract}

This study aims to analyze and explain the policy program; policy implementation; as well as the determinants that influence policy. The method that was used was descriptive qualitative and phenomenological approach. The data were collected through observation, interview, and document analysis. The data were analyzed using some steps namely data collection, data reduction, data presentation, data verification and conclusion. The results describe that (1) in terms of the policy program with (a) philosophical approach, the complex problems of poverty fishing occurs because the fishing communities live in the harsh natural atmosphere; (b) changing the way of thinking of fishermen and families are mobilizing role of women and children; (c) Juridical approach, the government does not maximally implement the use of regulation on poverty alleviation of the fishing communities; (2) in terms of the stages of the implementation which is measured through (a) socialization, $t$ has been socialized properly by the government to the fishing communities; (b) supervision, management of marine and fisheries involves community actively; (c) marketing facilities, provision of facilities and infrastructure has not been able to support change in society's living standards; (3) determinant factor: (a) Coordination among Regional Work Units, have constraints in providing services, and it has not in accordance with the work patterns of fishermen; (b) there has been no gas stations construction, there are only diesel tanks, (c) Cold Storage has not been constructed since the catches of fishermen are usually sold out; (d) In the case of small and medium-sized businesses, the alternative fishing effort has not been institutionalized. The government gives motivation to the fishermen in order to carry out other activities; (d) In the case of business credit, bank channeling KUR limit the disbursement of funds, so that the traditional fishermen is hard to obtain bank loans because the requirements are difficult felt by the fishing communities.

Keywords: Poverty Alleviation Policy, Traditional Fisherman, Policy Program

\section{Introduction}

\subsection{Background}

Noble ideals of the Indonesian nation are mandated in the Preamble of the Constitution of 1945 . There should be a change in the paradigm of national development of land-based development into a one-based development and evolved into a water-based development. It means that development in the land should be dovetailed and integrated proportionally with the socio-economic development in the sea, as well as the development in space. If all the elements in Indonesia are proportionally synergized with development in marine, it will produce sustained economic growth in addressing the problems of development and poverty towards the advanced and prosperous nation of Indonesia.

Poverty is a complex and multidimensional an issue, both from the aspect of cultural and structural aspects. Structural poverty occurs due to the inability of the system and social structure in providing opportunities that enable the poor to work. Cultural poverty refers to a way of living person or group of people caused by lifestyle, habits and culture such as lazy, undisciplined, wasteful (Suharto, 2010). The poverty of fishermen is categorized as structural poverty. Four main problems cause poverty, namely lack of opportunity, low of capabilities, low-level security, limited social rights, economic, and political causing vulnerability, noiselessness, and powerlessness in all areas (Imron,2009). 
The problem of poverty is still occupied a high position that needs special attention in Indonesia. One of the groups that could be said to be poor is a family of fishermen, especially traditional fishermen (Retno, 2010). Traditional fishermen are fishermen who exploit fishery resources with traditional fishing equipment in which they have a small venture capital and poor fishing organizations (Kusnadi, 2011).

Poverty alleviation is performed by making the fishing community as the object which is the fabric that is intertwined in establishing a poverty trap. For example, in the form of giving aid regarding the fishing tools, it does not refer to the needs of fishermen because fishermen pay the assistance, and it is a package that has been determined from the arbiter, and it tends to be similar among the various regions. Therefore, the aid system is top-down in nature, resulting in the aid becomes ineffective. Supposedly, type of aid is not solely determined by the arbiter. It should be based on a dialogue conducted by the local community. In this way, the fishermen are positioned as subjects in the development of fisheries so that the type of the provided aid will be actually suitable with what the fishermen needed.

Local governments have an important role in poverty alleviation programs. They choose the people who deserve to have economic assistance and the empowerment of community participation to create a conducive situation in the region. As the front guard in Indonesian government in providing public services to the community, local governments need to ensure the availability and affordability of basic needs in the area so that the people are not burdened with unreasonable economic costs, including the threat of scarcity and rising prices (inflation) of the basic commodities.

Government programs on the improvement of livelihoods of fishermen consists of:

1. The low-cost of house construction;

2. Alternative and additional work for the families of fishermen;

3. The scheme of small medium businesses and small loans;

4. The development of solar gas station;

5. The construction of cold storage;

6. The low cost of public transportation;

7. The facilities of school and health centers; and

8. The bank facilities.

The excellent programs are expected to accelerate poverty alleviation of traditional fishing. The government makes some of the policies in order to reduce the poverty of traditional fishing communities and to improve the lives of the fishermen. Therefore, the actualization of poverty alleviation for traditional fishermen in Palopo in the level of implementation through development programs for traditional fishing communities still face a problematic situation. The government policy in the form of regulations cannot be implemented maximally due to some of the faced constraints. The first is the lack of coordination on the implementation of existing policies. The second is the lack of interconnection between the strategy and implementing policy. The third is the sustainability aspects which have not been a concern.

Based on the above description, the researchers proposed some objectives if this study. The first is to analyze the policy of poverty alleviation program of traditional fishermen in Palopo. The second is to analyze the stages of the implementation of poverty alleviation policy of traditional fishermen in Palopo. The third is to describe the determinant factors which influence the process of implementation of poverty alleviation policy of traditional fishermen in Palopo.

\section{Literature Review}

Keban $(2008$, p. 55) revealed that public policy can be seen as a philosophical concept, as a product, as a process, and as a framework. Policy as a philosophical concept is a set of principles or the desired conditions. Policy as a product means that the policy is seen as a series of conclusions or recommendations. The policy as a process means that the policy is seen as a way in which an organization can find out what is expected, such as programs and mechanisms in achieving its products. Policy as a framework means that policy is a process of bargaining and negotiating to formulate the issues and methods of implementation

From these opinions, it can be affirmed that each product must concern the substance of the objectives of the policy and the condition of the policy. It should create a recommendation that takes into account a variety of programs that can be run and implemented to achieve the objectives of the policy.

Edwards III (1980, p. 1) states that: "The study of policy implementation is crucial for the study of public administration and public policy. Policy implementation, as we have seen, is the stage of policymaking between the establishment of a policy - such as the passage of a legislative act, the issuing of an executive order, the handing down of a judicial decision, or the promulgation of a regulatory rule - and the consequences of the policy for the people whom it affects. If a policy is inappropriate, if it cannot alleviate the problem for which it was designed, it will probably be a failure no matter how well it is implemented. However, even a brilliant policy poorly implemented may fail to achieve the goals of 
its designers"

The implementation of the policy regarding the substance is the right way to carry out the policy so that good policy can achieve objectives that have been set by policy makers. Dunn (2000) asserts that the implementation of the policy is the implementation and control of the direction of policy actions to achieve policy outcomes. It is generally formulated with its own strategies regarding the decision for the activities of governmental administration or the state government in conducting the mission. It is usually performed in the form of formal activities. The policy that has been made is executed by administrative units which are mobilizing financial and human resources.

Gow and Mors in Keban (2010, p. 78) state that there are various obstacles in the implementation of policies for poverty alleviation fishermen. The first obstacle is the political, economic, and environmental. The second is the weakness of institutions. The third is the inability of human resources in the field of technical and administrative. The fourth is a shortage of technical assistance. The fifth is the lack of decentralization and participation. The sixth is timing. The seventh is the supporting information system. The eighth is the difference of purposes agenda among the actors. The ninth is the ongoing support. All these obstacles are easily distinguishable whether they are internal or external obstacles.

\section{Methods}

\subsection{The Location and Type of the research}

This research was conducted in three villages in Palopo, South Sulawesi Province. They were Penggoli Village, a Village, and Sabbamparu Village. This research was a qualitative research with descriptive method interpretative (Denzim and Lincolin $(2009$, p. 266). There were two types of data namely primary data and secondary data. The primary data were obtained through in-depth interviews with respondents. They were also derived from observations concerning the implementation of policies to provide economic assistance for the traditional fishermen. The secondary data were obtained through literature review and also from various literature such as documents, writings, and the study of literature in the form of legislation, the Internet, and newspapers.

\subsection{Data Collection and Data validation}

In order to obtain data which were relevant to the discussion of this paper, the researchers conducted data collection techniques step by steps as follows:

1. Direct Interview was conducted by researchers using the principle of appropriateness in which the informants have the knowledge, and they are directly involved in the activities of the complaints and the principle of adequacy. In addition, the number of informants was determined according to the appropriateness of the information obtained by the researchers. Therefore, researchers conducted in-depth interviews with the staff who were directly related, such as: (1) the Mayor of Palopo; (2) Department of Marine and Fisheries; (3) Department of Cooperatives of SMEs; (4) Public Health; (5) Department of National Planning; (6) Central Statistics Office of Palopo, and; (7) Traditional fishermen.

2. The observation was a data collection technique for filtering data when the incident took place. The researchers observed the activity in relation to poverty alleviation policies, and they attempted to capture the meaning of the activity and behavior of the informants.

3. The documents were used to filter the information that was presented in the form of documents, such as written policies or rules associated with implementing poverty alleviation policy of traditional fishing.

The data were validated through several ways. The first was an extension of the observations. The second was an increase persistence of researchers in the observations and interviews. The third was the triangulation of sources and methods by checking the things that have been investigated. The fourth was the Focus Group Discussion. It was the effort of researchers to explore every problem as a focus of research. The fifth was negative case analysis by verifying and analyzing cases from the negative nuances and the adequacy of reference.

\subsection{Data Analysis}

The analysis of the data used in this research was qualitative descriptive analysis by using the phenomenological interactive model by looking at the processes associated with the implementation of poverty alleviation policy (Miler and Huberman, 2009). By using a phenomenological interactive model, there were three components of the analysis, namely 
data reduction, data presentation, and conclusion for verification.

\section{Results and Discussion}

\subsection{The program of poverty alleviation policy}

The policy implementation program regarding poverty alleviation of traditional fishermen in Palopo is in the form of Tridaya both the physical, economic and social areas with some activities. The first is an increase in social power in the form of scholarships and living allowance for people with disabilities and the elderly. The second is skills training. The third is the economic improvement of the productive society. Community activities through joint business groups and community organizations with self-supporting agencies can accelerate the accelerated environmental improvement. They can strengthen their economic and business. They are also able to educate the public to understand the sense of direct participation in all stages of development in the village where they live. Regional working groups are very enthusiastic through motivation and involvement in every stage of policy implementation of poverty alleviation program of traditional fishermen.

The implementation of the poverty alleviation policy of traditional fishermen will be one of a very powerful medium for implementing local government policy, and in the end, the government will act as a facilitator. Therefore, it can be viewed in some perspectives as follows.

The philosophical approach commercial by analyzing the degrees of truth for the meaning of poverty eradication policy program of traditional fishing. The most important thing in the process of poverty eradication is how the foundation of government policy, particularly in Palopo, provides public policy according to the needs of society, with the provisions that are adapted to the local norms. It can be said that fishing communities are not optimally taking part in education and training. They also have not maximally touched by modern technology so that it resulted in the low ability of fishermen and fishing communities are covered the atmosphere of uncertainty in the future leading to a lower quality of fishery resources and low income. Therefore, it can be assumed that the poverty eradication program for traditional fishermen has not yet benefited.

The sociological approach is analyzing the degree of conformity between people's lives and the policies of poverty alleviation of traditional fishermen. The government sought to change the way of thinking of fishermen and their families, particularly regarding the ability to manage their finances, adjusted by the standard conditions and scarcity. The cultural habits of fishermen such as lazy and living lavishly are regarded as a cause of the poverty of fisherman, in fact, if the culture is observed, the fishermen have a reliable work ethic. Strategy undertaken by the local government of Palopo is the mobilization of the role of women (the wives) and children for a living. Women are directly involved in activities of social and economic institutions, such as gathering, recitals, savings, and loans (economic enterprise), and the social networks which they usually use to support the family's survival. The presence of these institutions is a fishing community adaptation strategy to face the encountered difficulties.

The judicial approach is analyzing the degree of conformity between the program of poverty alleviation policy for traditional fishing and the legislation in force. The utilization of valid regulations in Palopo which regulates the role of fishermen in all their daily activities and put traditional fishermen as a subject in the management and utilization of coastal resources can be measured in the regulations that have been effective. The use of regulation to alleviate the poverty of fishermen community has not been implemented maximally in Palopo. Therefore, it is necessary for the seriousness of the local government of Palopo to empower the fishing communities, so that people who still have productive age in the coastal areas have a decent quality of life.

\subsection{The stages of the implementation of poverty reduction policies for traditional fishermen}

The socialization of policy is a presentation of the policy about the poverty alleviation policy for traditional fishermen in order to know and understand the policy in the form of formal and non-formal. The government has socialized to traditional fishing communities, but the intensity and the seriousness of the government are not maximal so that fishing communities are not responsive maximally toward the government policy. Another cause is the low level of education of traditional fishermen. Thus, the government should seek a formulation and better technique, so that fishing communities are more concerned and responsive to the implementation of marine policy appropriately. Hence, the survival of marine biodiversity can be maintained and continued to provide good expectation for coastal communities.

Supervision is performing guidance to fishermen about the right time, location, and potential screening techniques in modern marine resources, as well as guidance on alternative employment. The local government has already provided 
guidance on the management of marine and fishery management of the fishing communities. The government also has developed public economic activities based on local resources, by supporting the establishment of the economic enterprise for the fishermen who live in the coastal city of Palopo. However, the fishing community has not understood the policy and program maximally launched by the government. It is due to the low knowledge and education owned by the fishing communities. Therefore, the responsibility and seriousness of the local government are required in addressing the poverty problem of traditional fishermen.

The facilities for the marketing of products are the provision of potential facilities and infrastructure for marketing the product of fishermen. The local government of Palopo has facilitated traditional fishing by monitoring and controlling illegal fishing. The procurement of public infrastructure consists of the affordable transport for the transportation of fishing production to the marketplace (market, auctions) for the proper marketing and the existence of consumer or collector that are ready to buy the harvest of fishermen at reasonable prices. However, the provision has not been able to support the changes in the living standards of fishing communities to be better.

\subsection{The determinant factors that influence the policy}

Coordination among the authorized regional work units is the implementation of coordination among agencies that have the authority (Local Government, Transportation Department, Public Works Department, Diskop and SMEs, health office, Diaspora, Despines, and Disputa) at the implementation of poverty alleviation programs traditional fishing, to be able to sort through programs that are priorities. The coordination of the authorized regional work units in Palopo in providing services to the needs of the public through musrembang or rural development planning has no constructive effect on traditional fishing communities. It is not in accordance with the priority target of the needs of fishermen, and the results of musrembang are not realized maximally in the poverty alleviation program of traditional fishing communities.

The construction of gas stations is the facility to obtain fuel for the engine of a fishing boat to do the filtering of marine wealth. There is not yet a gas station around the residence of traditional fishermen. It is only a holding tank of fuel oil. Fuel supplies for traditional fishermen have not been adequate in Palopo, and it affects the scarcity of gasoline and diesel. It has been complained by the fishermen in Palopo. In addition, there are plans of private parties to develop their fishing locations around the gas station. However, there is a worry regarding a loss. The distribution of fishing tools is not effective without adequate fuel supplies. Therefore, the working relationship based on economic aspects and mutual interdependence does not provide support for the income for the survival of the traditional fishermen. Thus, the fulfillment of fuel needs are difficult to obtain, and the price is quite high.

The construction of Cold Storage is a storage facility for fishermen to freshen the fish production in order to maintain the quality of the fish. The local government wants to build adequate cold storage that has capacity in accordance with the needs of the fishermen. However, the needs of fishermen at this time is not Col Storage because the fish is inadequate. The catches of fishermen are usually sold out. Therefore, until today the presence of Cold Storage in Palopo is not yet realized. There is only a temporary storage warehouse so that the fish can last up to two days.

Small and Medium Enterprises (SMEs) are an alternative fishing effort to support the family income. The role of SMEs has been recognized by parties big enough in the national economy. There are some strategic roles of SMEs. The first is to absorb much labor because every investment create more employment opportunities. The second is the ability to utilize local raw materials and produce goods and services needed by the wider community, including traditional fishing communities in Palopo. One of the small and medium businesses that exist in the traditional fishing communities in Palopo is the manufacture of shredded fish and crab canning. However, the alternative traditional fishing effort has not been institutionalized. The government has provided the motivation and supervision of the fishermen in order to perform other activities outside fishing.

People's Business Credit (KUR) is funding assistance which is affordable by fishermen from executives to fishermen for fishing facilities to support the alternative income of fishermen. There are several objectives of KUR. The first is to accelerate the development of primary sectors and the empowerment of small-scale enterprises. The second is to improve accessibility toward credit and financial institutions. The third is to reduce poverty. The fourth is to expand employment opportunities. However, the reality is that banks which distribute KUR confine the disbursement of funds to the local communities in Palopo. Therefore, the fishermen are difficult to obtain a loan, because the requirements of banks are complicated felt by fishing communities, especially traditional fishermen in Palopo. In addition, loans granted by banks are limited. The problem is that fishermen are still overwhelmed in the return of funds in installments, as the result of small businesses that are run insufficient to pay the loan. Thus, banks are forced to forgive the creditors who cannot afford. However, in the future, there will be considered if they beg the credit lending. 


\section{Conclusion}

1. Poverty alleviation policy program of traditional fishing in Palopo in philosophical approach found that the fishing communities live in the harsh natural atmosphere which is always uncertainty. They have not been touched by modern technology. The quality of human resources is still low and the results is also low. The sociological approach found that the fishing communities in Palopo responds the poverty reduction policy. Juridical approach find that the utilization of regulation on poverty alleviation of fisheries communities has not been maximally implemented by the local government of Palopo.

2. In terms of the stages of poverty alleviation policy implementation of traditional fishing communities in Palopo with the socialization approach, it is found that the policy has been socialized properly by the government to fishing communities. However, the fishing community has different level of knowledge and response to the socialization. Supervision approach found that the management of marine and fisheries involves community actively. The government developed the economic based on local resources, by supporting the establishment of KUD. Production approach found that the government has facilitated fishing process, such as infrastructure, transport, market, auction, and collectors.

3. Determinant factors of the implementation of poverty alleviation policy of traditional fishermen in the coordination approach among the Regional Work Units found that in providing services to the needs of the public it is not in line with the work pattern that has been determined by the willingness of fishermen. The approach of building stations found that the important role of gas stations is perceived by the local communities. Cold storage approach concluded that the government did not build it because of catches of fishermen are always sold out. SMEs approach found that the alternative of fishermen has not been institutionalized. The government provides motivation and supervision of the fishermen in order to carry out other activities. KUR approach found that the participating banks of KUR limit the funds so that the public is very difficult to borrow money because bank requirements cannot be reached by traditional fishing communities

\section{References}

Anonim. (2011). Akar Kemiskinan Nelayan, Yogyakarta: LKiS.

Dahuri, Rokhmin. (2012). Pendayagunaan Sumber Daya Kelautan Untuk Kesejahteraan Rakyat. Jakarta: LISPI.

Denzin, Norman K. and Lincoln, Yvonna S. (2009). Qualitative Research, Yogyakarta: Pustaka Pelajar.

Dunn, N William. (2000). Pengantar Analisis Kebijakan Publik, Yogyakarta: Gajah Mada University Press.

Edwards III, George C. (1980). Implementing Public Policy, Washington D.C: Congressional Quarterly Press.

Gow dan Mors. (2010). Public Policy; Teori Kegiatan Analisis Kebijakan, Proses Kebijakan. Jakarta: Penerbit PT Elex Media Kompotindo.

Imron, Masyuri (ed). (2009). Pemberdayaan Masyarakat Nelayan. Yogyakarta: Media Pressindo.

Keban, Yeremias. T. (2008). Enam Strategis Administrasi Publik : Konsep, Teori dan isu. Yogyakarta: Gava Media.

Kusnadi. (2010). Nelayan: Strategi Adaptasi dan Jaringan Sosial, Bandung: Humaniora Utama Press.

Miles, Matthew B., and A. Michael Huberman. (2009). Qualitative dan analysis, 2nd ed. Thousand Oaks, CA: Sage.

Suharto, Edi. (2010). Kebijakan Sosial Sebagai Kebijakan Publik, Bandung: Alfabeta.

Tachjan. (2008). Implementasi Kebijakan Publik. Bandung: Penerbit AIPI Bandung-Puslit KP2W Lemlit Universitas Padjadjaran. 